Analytica Chimica Acta, 134 (1982) 411-415

Elsevier Scientific Publishing Company, Amsterdam - Printed in The Netherlands

Short Communication

\title{
SPECTROPHOTOMETRIC DETERMINATION OF MICROGRAM AMOUNTS OF PENICILLINS BY SOLVENT EX'TRACIIUN WI'IH AZURE B
}

\author{
ANANT N. NAYAK* \\ Department of Chemistry, Government College for Boys, Mandya 571401 , Karnataka \\ State (India) \\ P. G. RAMAPPA, H. S. YATHIRAJAN and S. MANJAPPA \\ Department of Post-Graduate Studies and Research in Chemistry, University of Mysore, \\ Manasagangotri, Mysore 570006 (India)
}

(Received 14th April 1981)

Summary. Penicillins are determined by means of ion-pair formation with azure B and extraction into chloroform: the absorbance of the extract is stable for several days. The apparent molar absorptivities for sodium penicillin $G$ and potassium penicillin $V$ at $634 \mathrm{~nm}$ are $3.91 \times 10^{3}$ and $1.25 \times 10^{3} 1 \mathrm{~mol}^{-1} \mathrm{~cm}^{-1}$, respectively. Calibration graphs are linear over the range $60-950 \mu \mathrm{g}$ of sodium penicillin $\mathrm{G}$ and $40-600 \mu \mathrm{g}$ of potassium penicillir. $\mathrm{V}$ in $10 \mathrm{ml}$. The method is successfully applied to pharmaceutical preparations.

The continuing introduction of new penicillin drugs has resulted in an extensive literature on their determination. The assay of antibiotics has been reviewed by Fairbrother [1]. Most chemical assays for the penicillins are based on the titration of unconsumed iodine after incubation with hydrolyzed penicillin [2]. An adaptation of this method is based on the reaction of penicillins with an excess of $N$-bromosuccinimide [3]. Adams et al. [4] proposed a novel enzymatic penicillin assay based on a pH-stat instrument incorporating coulometric generation of the titrant. Ibrahim et al. [5] determined penicillins by oxidizing with iodine monochloride and titrating the residual iodine monochloride with standard potassium iodate. Grime and Tan [6] determined some selected penicillins by direct titration with potassium iodate.

Spectrophotometric methods for penicillins have been based on the determination of the hydroxamic acid formed by reaction with hydroxylamine [7], or the penicillenic acid mercury(II) mercaptides formed by reaction with imidazole in the presence of mercury(II) chloride [8]. A method based on the formation of a coloured compound $\left(\lambda_{\max }=750 \mathrm{~nm}\right)$ by boiling penicillins with ammonium vanadate solution in sulphuric acid has been reported [9].

Azure B forms ion-pairs with various anions; such reactions have been 
used for extraction-spectrophotometric determinations of rhenium [10], antimony [11], uranium [12], etc. In a comprehensive investigation of analytical methods for penicillins, azure $B$ was found to give extractable ion-pairs with sodium penicillin $G$ and potassium penicillin $V$. The extraction of these ion-pairs provides a very sensitive spectrophotometric procedure which is applicable over a wide $\mathrm{pH}$ range with good selectivity.

\section{Experimental}

Apparatus and reagents. A Beckman DB spectrophotometer with 10-mm silica cells and in Elico L1-10 pH meter were employed. All chemicals were of analytical grade and were used without further purification. An azure B stock solution $\left(5 \times 10^{-3} \mathrm{M}\right.$ ) was prepared by dissolving $340.5 \mathrm{mg}$ of azure B in redistilled water, and diluting to $250 \mathrm{ml}$.

Penicillins. Pharmaceutical-grade benzyl penicillin sodium (sod. pen. G) and phenoxymethyl penicillin potassium (pot. pen. V) were obtained in sealed vials. Elemental analysis revealed no significant impurities. Standard stock solutions of penicillins were prepared by dissolution of appropriate amounts of solid in $100 \mathrm{ml}$ of $0.1 \mathrm{M}$ phosphate buffer solution, $\mathrm{pH} 5.91$.

Procedure. Pipette an aliquot of sample or standard solution containing $60-950 \mu \mathrm{g}$ of sod. pen. G or $40-600 \mu \mathrm{g}$ of pot. pen. V into a $50-\mathrm{ml}$ separating funnel. Add $5 \mathrm{ml}$ of buffer $\mathrm{pH} 5.0$ (14.74 g of $\mathrm{Na}_{2} \mathrm{HPO}_{4}$ and $10.20 \mathrm{~g}$ of citric acid per litre) and dilute to $20 \mathrm{ml}$ with redistilled water. Add $1 \mathrm{ml}$ of $1 \times 10^{-3} \mathrm{M}$ azure $\mathrm{B}$ solution and $10 \mathrm{ml}$ of chloroform. Shake the funnel for $2 \mathrm{~min}$ to extract the ion-pair formed between azure $B$ and penicillin. After standing for a fixed time between $5 \mathrm{~min}$ and $2 \mathrm{~h}$, transfer the organic phase to a 15-ml glass-stoppered tube containing some anhydrous sodium sulphate. Shake the mixture vigorously until transparent and measure the absorbance at $634 \mathrm{~nm}$ against a reagent blank. Construct a calibration graph from the standard measurements.

For the analysis of pharmaceutical preparations, dissolve an appropriate amount of sample in the phosphate buffer to obtain a ca. 200-ppm solution of penicillin and filter if necessary. Then apply the above procedure.

\section{Results and discussion}

Figure 1 shows the absorption spectra of the azure B-penicillin ion-pairs extracted into chloroform, and of the reagent blank. All these spectra have their absorption maxima at $634 \mathrm{~nm}$ and this wavelength was used in all subsequent measurements. The wavelength of maximum absorption did not shift with a change in buffer composition at a given $\mathrm{pH}$, when acetate and McIlvaine buffers were tested.

To establish the optimum $\mathrm{pH}$ range, penicillin was allowed to react with azure $B$ in aqueous solutions buffered to $\mathrm{pH} 0.7-8.0$ and the complex formed was extracted into chloroform for measurement. Sulphuric acid was used for adjustment to below $\mathrm{pH} \mathrm{2.2,} \mathrm{and} \mathrm{McIlvaine} \mathrm{buffers} \mathrm{[13]} \mathrm{for} \mathrm{pH}$ values in the range $2.2-8.0$. Constant absorbances were obtained over the $\mathrm{pH}$ 

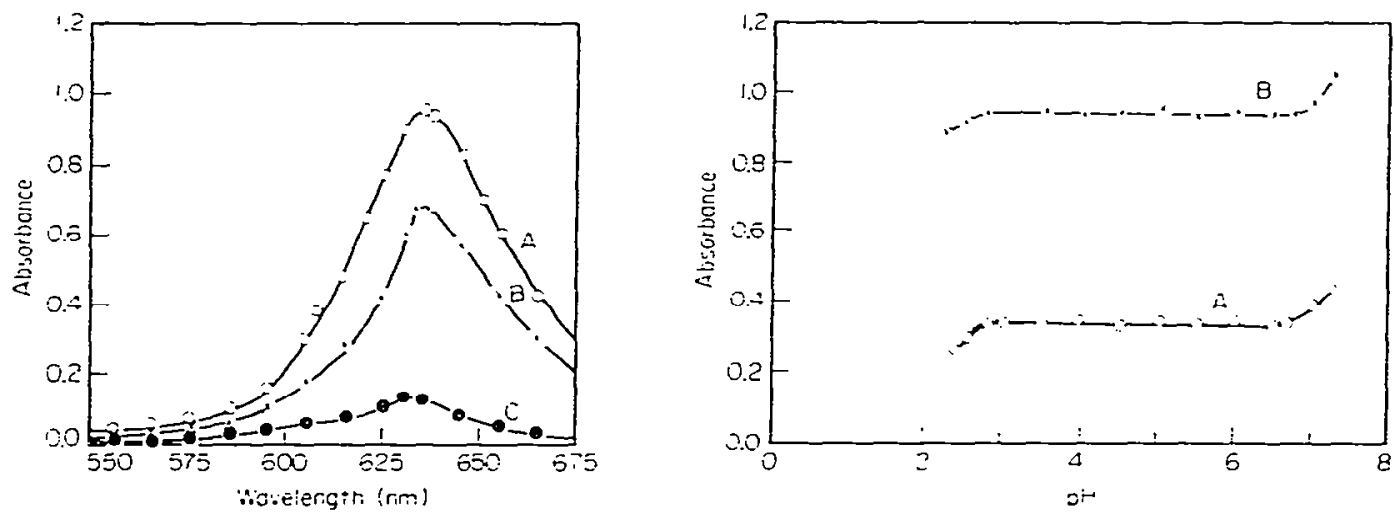

Fig. 1. Absorption spectra of azure $B$ ion-pairs in chloroform: (A) 30 ppm potassium V (reagent blank subtracted); (B) $60 \mathrm{ppm}$ sodium penicillin $G$ (reagent blank subtracted); (C) reagent blank against chloroform.

Fig. 2. Effect of pH on the formation of the ion-pairs of azure B with (A) socium penicillin $G$; (B) potassium penicillin $V$ (reagent blank subtracted).

range 2.8-6.6 (Fig. 2). The decreased absorbance below pH 2.8 can be attributed to a decrease in the concentration of free penicillin ion caused by protonation. The increased absorbance above $\mathrm{pH} 6.6$ is caused by the formation of an extractable azure B species. In all subsequent work, a pH of ca. 5.0 was used.

The extraction of the ion-pair was affected by the concentration of azure B. To establish the optimal amount, $1-\mathrm{ml}$ aliquots of $10^{-4}-2 \times 10^{-3} \mathrm{M}$ azure $B$ solutions were used in the conditions given above. Calibration graphs with $1 \mathrm{ml}$ of $1 \times 10^{-4}$ or $2.5 \times 10^{-4} \mathrm{M}$ azure $\mathrm{B}$ were not linear but the reagent blanks were low. The graphs with $5 \times 10^{-4}-2 \times 10^{-3} \mathrm{M}$ azure $\mathrm{B}$ solutions were linear, but the more azure $B$ used, the higher the reagent blank. In subsequent work $1 \mathrm{ml}$ of $1 \times 10^{-3} \mathrm{M}$ azure $\mathrm{B}$ was employed. The method of continuous variations indicated that a single $1: 1$ ion-pair species was extracted.

To establish the optimal extraction conditions, solutions containing $400 \mu \mathrm{g}$ of penicillin in redistilled water were treated with azure $\mathrm{B}$ as recommended and then extracted with successive $10-\mathrm{ml}$ portions of chloroform, the absorbance of the organic phase after each extraction being measured against chloroform at $634 \mathrm{~nm}$. The absorbance of the fifth extract was very similar to that of the fifth reagent blank, indicating that four $10-\mathrm{ml}$ portions of chloroform suffice for complete extraction. However, the reproducibility with a single extraction was so good that, for simplicity, one $10-\mathrm{ml}$ portion of chloroform was used in the recommended procedure. Tests made on sodium penicillin $\mathrm{G}(40 \mathrm{ppm})$ with the single extraction gave a mean result of $39.8 \mathrm{ppm}$ with a standard deviation of $0.27(n=5)$. Other organic solvents were tested, but chloroform was found to be the most suitable. 
Shaking times of $0.5-5 \mathrm{~min}$ produced constant absorbance, and so shaking for $2 \mathrm{~min}$ was used throughout. In contrast, increasing standing times ( $5 \mathrm{~min}-3 \mathrm{~h}$ ) after shaking produced a slight increase in absorbance for both the reagent blank and the ion-pair. The reproducibility was good on standing for a fixed period; for example, measurements on 40-ppm solutions after 10-min standing times showed standard deviations of about $0.3 \mathrm{ppm}(n=10)$. The absorbances of the separated extracts were, however, stable for 5 days in a glass-stoppered tube at room temperature.

Calibration graphs showed a linear dependence of absorbance on concentration over the ranges $6-95 \mathrm{ppm}$ of sodium penicillin $\mathrm{G}$ and $4-60 \mathrm{ppm}$ of potassium penicillin V. For $\log I_{0} / I=0.001$, the Sandell sensitivities were 0.691 and $0.031 \mu \mathrm{g} \mathrm{cm}$, respectively, and the corresponding apparent molar absorptivities were $3.91 \times 10^{3}$ and $1.25 \times 10^{4} 1 \mathrm{~mol}^{-1} \mathrm{~cm}^{-1}$.

Effect of concomitant substances and applications to penicillin drugs. The effects of some compounds which often accompany penicillin in pharmaceutical products were studied. The compounds were added to $40-\mathrm{ppm}$ penicillin solutions and studied by the recommended procedure. The tolerance limits are given in Table 1 . The proposed method has the advantage of virtual freedom from interference and should be of value in the trace determination of penicillins in many samples.

The proposed method was successfully applied to the determination of penicillins in various pharmaceutical preparations. The results of the assays of tablets and vials (Table 2) compare favourably with the quoted values, and with those obtained by the official method of the British Pharmacopoeia [14].

The authors thank Hindustan Antibiotics Ltd., India, for the supply of pharmaceutical-grade penicillins.

TABLE 1

Eff:et of concomitant substances on the determination of penicillin ( $40 \mathrm{ppm}$ )

\begin{tabular}{|c|c|c|c|c|c|}
\hline \multirow{2}{*}{$\begin{array}{l}\text { Compound } \\
\text { added }\end{array}$} & \multicolumn{2}{|c|}{ Tolerance limit ${ }^{a}(\mathrm{ppm})$} & \multirow{2}{*}{$\begin{array}{l}\text { Compound } \\
\text { added }\end{array}$} & \multicolumn{2}{|c|}{ Tolerance limit ${ }^{a}$ (ppm) } \\
\hline & Sod. pen. G & Pot.pen. V & & Sod. pen. G & Pot. pen' \\
\hline Ascorbìc acid & 120 & 130 & Sucrose & 6500 & 6300 \\
\hline Benzoic acid & 250 & 275 & Barbitone & 2000 & 2200 \\
\hline Citric acid & 4500 & 4300 & Gelatin & 5500 & 5800 \\
\hline 4-Hydroxybenzoic acid & 325 & 300 & Gum acacia & 10000 & 9500 \\
\hline Sorbic acid & 500 & 550 & Reserpine & 300 & 300 \\
\hline Stearic acid & 850 & 800 & Sodium alginate & 700 & 800 \\
\hline Tartaric acid & 7800 & 8000 & $\mathrm{NaHCO}_{3}$ & 1400 & 1500 \\
\hline Dextrose & 5500 & 5800 & Starch & 4000 & 4200 \\
\hline Lactose & 4500 & 4500 & Talc & 4500 & 4600 \\
\hline Maltose & 5000 & 5000 & & & \\
\hline
\end{tabular}

amount causing an error of $\pm 2.5 \%$. 
TABLE 2

Determination of penicillins in commercial pharmaceutical preparations

\begin{tabular}{|c|c|c|}
\hline \multirow[t]{2}{*}{ Preparations } & \multicolumn{2}{|c|}{ Mean recovery ${ }^{a}(\%)$} \\
\hline & B.P. method & Proposed method \\
\hline $\begin{array}{l}\text { Pot. pen. } \mathrm{V}^{\mathrm{b}} \\
(125 \mathrm{mg} / \mathrm{tab}) \\
(250 \mathrm{mg} / \mathrm{tab}) \\
\text { Sod. pen. G }{ }^{\mathrm{b}} \\
\text { (500000 U/vial) } \\
\text { (1000000 U/vial) } \\
\text { Sod. pen. Gc } \\
(200000 \mathrm{U} / \mathrm{vial}) \\
(500000 \mathrm{U} / \mathrm{vial}) \\
(1000000 \mathrm{U} / \mathrm{vial})\end{array}$ & $\begin{aligned} 102.3 & \pm 1.2 \\
98.8 & \pm 0.8 \\
98.2 & \pm 1.1 \\
101.6 & \pm 0.8 \\
102.4 & \pm 0.6 \\
96.8 & \pm 1.5 \\
101.2 & \pm 1.2\end{aligned}$ & $\begin{aligned} 102.7 & \pm 1.4 \\
99.4 & \pm 0.7 \\
98.6 & \pm 1.3 \\
102.0 & \pm 0.6 \\
102.1 & \pm 0.7 \\
96.4 & \pm 1.6 \\
100.8 & \pm 0.8\end{aligned}$ \\
\hline
\end{tabular}

a Average of five determinations with standard deviation. ${ }^{b}$ Marketed by Hindustan Antibiotics Ltd. "Marketed by Squibb.

\section{REFERENCES}

1 J. E. Fairbrother, Pharm. J., 218 (1977) 509.

2 J. F. Alicino, Ind. Eng. Chem. Anal. Ed., 18 (1946) 619.

3 J. F. Alicino, J. Pharm. Sci., 65 (1976) 300.

4 R. E. Adams, S. R. Betso and P. W. Carr, Anal. Chem., 48 (1976) 1989.

5 E. A. Ibrahim, S. M. Rida, Y. A. Beltagy and M. M. Abd El-Khalek, J. Drug Res. (Egypt), 6 (1974) 13.

6 J. K. Grime and B. Tan, Anal. Chim. Acta, 105 (1979) 361.

7 G. E. Boxer and P. M. Everett, Anal. Chem., 21 (1949) 670.

$8 \mathrm{H}$. Bundgaard and K. Ilver, J. Pharm. Pharmacol., 24 (1972) 790.

9 E. A. Ibrahim, Y. A. Beltagy and M. M. Abd El-Khalek, Talanta, 24 (1977) 328.

10 V. M. Tarayan and S. V. Vartanyan, Dokl. Akad. Nauk Arm. SSR, 47 (1968) 214.

11 V. M. Tarayan, E. N. Ovsepyan and M. G. Ekimyan, Uch. Zap. Erevan Univ. Estestv. Nauk, 1 (1972) 73.

12 V. M. Tarayan, E. N. Ovsepyan and A. A. Petrosyan, Zh. Anal. Khim., 26 (1971) 322.

13 H. T. S. Britton, Hydrogen Ions, Vol. 1, Chapman and Hall, London, 1955, p. 356.

14 British Pharmacopoeia, HMSO, London, 1973, pp. 52, 363. 